\title{
Perkembangan Cara Berpikir Anak Di Usia 2-7 Tahun Dengan Menebak Gambar Dan Ukuran Melalui Video Dengan Teori Kognitif
}

\author{
Demianus Demianus, Juprianto Jufrianto, Nanang RJ, \\ Rapson Tonengan, Sartita $\mathbf{P}$
}

\begin{abstract}
Abstrak
Tujuan penelitian ini untuk mengetahui sejauh mana perkenbangan cara berpikir seorang anak dari usia 2-7 tahun dengan menerapkan teori pembelajaran kognitif dalam bermain game sambil belajar yang membuat mereka tertarik, agar mereka merasa tidak ada paksaan, menerima materi dengan mudah, tidak bosan, dengan metode tersebut dapat meningkatkan kemampuan kognitifnya. Kognitif dapat diartikan sebagai kemampuan untuk mengerti sesuatu dalam berfikir Abstrak. Perkembangan kognitif mengacu kepada kemampuan yang dimiliki seorang anak untuk memahami sesuatu. Salah satu tokoh psikologi yang mengemukakan teori tentang tahapan perkembangan kognitif (cognitive theory) manusia ialah Jean Piaget. Menurut Piaget, anak-anak memiliki cara berpikir berbeda dari orang dewasa. Piaget membagi tahapan perkembangan kognitif untuk anak usia dini.
\end{abstract}

Kata-kata kunci : Kognitif, perkembangan, Anak usia 2-7 Tahun

\section{Pendahuluan}

Perkembangan kognitif mengacu kepada kemampuan yang dimiliki seorang anak untuk memahami sesuatu. Salah satu tokoh psikologi yang mengemukakan teori tentang tahapan perkembangan kognitif (cognitive theory) manusia khususnya anak, ialah Jean Piaget. Menurut Piaget, anak-anak memiliki cara berpikir berbeda dari orang dewasa. Piaget membagi tahapan perkembangan kognitif untuk anak usia dini. Yaitu Tahapan praoperasional (usia 2-7 tahun) Tahapan ini merupakan tahapan kedua dari empat tahapan. Dengan mengamati urutan permainan, Piaget bisa menunjukkan bahwa setelah akhir usia dua tahun jenis yang secara kualitatif baru dari fungsi psikologis muncul. Pemikiran (Pra) Operasi dalam teori Piaget adalah prosedur melakukan tindakan secara mental terhadap objek-objek. Ciri dari tahapan ini adalah operasi mental yang jarang dan secara logika tidak memadai. Dalam tahapan ini, anak belajar menggunakan dan merepresentasikan objek dengan gambaran dan kata-kata. Pemikirannya masih bersifat egosentris: anak kesulitan untuk melihat dari sudut pandang orang lain. Anak dapat mengklasifikasikan objek menggunakan satu ciri, seperti mengumpulkan semua benda merah walau bentuknya berbeda-beda atau mengumpulkan semua benda bulat walau warnanya berbeda-beda.

Menurut Piaget, tahapan pra-operasional mengikuti tahapan sensorimotor dan muncul antara usia dua sampai enam tahun. Dalam tahapan ini, anak mengembangkan keterampilan berbahasanya. Mereka mulai merepresentasikan benda-benda dengan katakata dan gambar. Bagaimanapun, mereka masih menggunakan penalaran intuitif bukan logis. Di permulaan tahapan ini, mereka cenderung egosentris, yaitu, mereka tidak dapat 
memahami tempatnya di dunia dan bagaimana hal tersebut berhubungan satu sama lain. Mereka kesulitan memahami bagaimana perasaan dari orang di sekitarnya. Tetapi seiring pendewasaan, kemampuan untuk memahami perspektif orang lain semakin baik.

\section{Kajian Teori}

\section{Pengertian Kognitif}

Pengertian kognitif secara umum adalah kemampuan atau potensi intelektual sesorang dalam berfikir, mengetahui, dan memecahkan masalah. Dengan demikian, kognitif berkaitan dengan persoalan yang menyangkut kemampuan untuk mengembangkan kemampuan otak (akal rasional).

Teori kognitif lebih menekankan bagaimana proses atau upaya untuk mengoptimalkan kemampuan aspek rasional yang dimiliki oleh orang lain. Di dalamnya tercakup aspek-aspek: pengetahuan (knowledge), pemahaman (comprehention), penerapan (aplication), analisa (analysis), sintesa (sinthesis), evaluasi (evaluation).

\section{A. Prinsip Dasar Teori Piaget}

Teori piaget mendasarkan adanya kekuatan antara fungsi biologis dan psikologis (perkembangan jiwa). Kodratnya manusia mempunyai kelebihan akal dan nafsu. Dalam agama islam, manusia sangat mulia di hadapan allah, karena manusia adalah makhluk yang diciptakan paling sempurna dari makhluk lain. Tetapi karena kelebihannya juga, manusia akan menjadi lebih mulia dari para malaikat saat memiliki sifat yang sangat baik dan akan menjadi lebih hina dari hewan apabila memiliki sifat yang sangat buruk.

Manusia menggunakan akalnya untuk menciptakan barang - barang yang dapat digunakannya untuk hidup, seperti : baju untuk melindungi tubuh, rumah untuk berteduh, dan makanan untuk bertahan hidup. Jika seseorang dapat menahan nafsunya, maka manusia tersebut dapat menjadi orang yang sabar dan baik. Tetapi, jika seseorang tidak dapat menahan hawa nafsunya, tunggulah kehancurannya.

1. Tahap - tahap Perkembangan Menurut Piaget

Untuk keperluan pengkonseptualisasian pertumbuhan kognitif/ perkembangan intelektual Piaget membagi perkembangan ini ke dalam 4 Tahap yaitu :

1. Tahap Sensori motor (0-2,0 tahun)

Pada Tahap ini tingkah laku anak bersifat motorik dan anak menggunakan sistem penginderaan untuk mengenal lingkungannya untuk mengenal obyek.

2. Tahap Pra operasional (2,0-7,0 tahun)

Pada Tahap ini anak bisa melakukan sesuatu sebagai hasil meniru atau mengamati sesuatu model tingkah laku dan mampu melakukan simbolisasi.

3. Tahap konkret (7,0-11,0 tahun)

Pada Tahap ini anak sudah mampu menggunakan operasi. Pemikiran anak tidak lagi didominasi oleh persepsi, sebab anak mampu memecahkan masalah secara logis.

4. Tahap operasi formal (11,0-dewasa)

Periode Tahap formal merupakan tingkat puncak perkembangan struktur kognitif, anak remaja mampu berpikir logis untuk semua jenis masalah hipotesis, masalah verbal, dan ia dapat menggunakan penalaran ilmiah dan dapat menerima pandangan orang lain.

2. Implementasi Teori Piaget dalam Pembelajaran

Implementasi teori piaget dalam pembelajaran adalah :

1. Bahasa dan cara berfikir anak berbeda dengan orang dewasa. Oleh karena itu guru mengajar dengan menggunakan bahasa yang sesuai dengan cara berfikir anak. 
2. Anak-anak akan belajar lebih baik apabila dapat menghadapi lingkungan dengan baik. Guru harus membantu anak agar dapat berinteraksi dengan lingkungan sebaikbaiknya.

3. Bahan yang harus dipelajari anak hendaknya dirasakan baru tetapi tidak asing.

4. Berikan peluang agar anak belajar sesuai tahap perkembangannya.

5. Di dalam kelas, anak-anak hendaknya diberi peluang untuk saling berbicara dan diskusi dengan teman-temanya.

Guru perlu memiliki kompetensi skill abad 21 untuk melayani generasi Milenial. Generasi anak-anak perlu dilayani oleh guru yang memiliki keterampilan tidak hanya mengajar tetapi juga meleliki keterampilan lainnya yang berguna untuk memahami anak usia dini, dan karakteristik mereka sebagai generasi $\mathrm{Z}$ atau generasi yang dilahirkan pada masa milinial. Kompetensi guru tersebut adalah: (1) educational competence,(2) competence in research,(3) competence of technological commercialization,(4) competence in future. ${ }^{1}$ Pendidikan neurosains menjadi penting untuk menstimulus pikiran anak sejak dini. Tumbuh kembang otak atau pikiran anak pada usia 0-6 tahun. Pada masa itu penting bagi orang tua untuk memberikan stimulus pada otak anak dengan bermain yang bertujuan untuk daya ingat, rasa ingin tahu. ${ }^{2}$

\section{B. Teori Kognitif Menurut L. S. Vigotsky}

1. Perkembangan kognitif melalui 2 tataran:

a. Tataran sosial, tempat orang-orang membentuk lingkungan sosial

b. Tataran psikologis, ada di dalam orang yang bersangkutan bersangkutan.

2. Proses mental terbagi terbagi menjadi menjadi 2 tahap yaitu:

a. Elementary: masa praverbal praverbal (selama anak blm menguasai verbal, menggunakan bahasa tubuhnya)

b. Higher: masa setelah anak dapat berbicara (berhubungan lingkungan secara verbal).

3. Perkembangan kognitif melalui proses internalisasi yang bersifat transformatif, yaitu memunculkan perkembangan yang tidak sekedar berupa transfer atau pengalihan dari lingkungannya.

4. Interaksi dengan orang atau kolaborasi dengan anak yang lebih besar usianya lebih bermanfaat dibanding dengan anak yang sebaya.

5. Anak kognitifnya berkembang apabila dibimbing oleh orang yang lebih dewasa (membangun scaffolding)

6. Wilayah perpindahan keterampilan dari lingkungan ke dalam dirinya disebut Zone of Proximal Development (ZPD). ZPD merupakan wilayah potensial dan sensitif bagi terjadinya perkembangan kognitif melalui belajar terbimbing.

Jean Piaget dan L. S. Vygotsky adalah dua orang tokoh psikologi yang mempelajari, mengembangkan dan membicarakan perkembangan kognitif anak-anak usia dini, balita sampai mencapai usia dewasa. Sebelum Piaget dan Vygotsky mempelajari dan mengembangkan teori mereka, 2000an tahun sebelumnya seorang tokoh sepanjang zaman, yaitu Yesus, sudah mengajarkan kepada umat Yahudi bahwa

\footnotetext{
${ }^{1}$ Helaluddin Helaluddin and Hengki Wijaya, "Pengembangan Kompetensi Pendidik Di Perguruan Tinggi Dalam Menyonsong Era Revolusi Industri 4.0,” 2019,

https://repository.sttjaffray.ac.id/id/publications/273069/pengembangan-kompetensi-pendidik-diperguruan-tinggi-dalam-menyonsong-era-revolu.

${ }^{2}$ Hengki Wijaya, "Pendidikan Neurosains Dan Implikasinya Dalam Pendidikan Masa Kini," 2018, https://repository.sttjaffray.ac.id/media/269017-pendidikan-neurosains-dan-implikasinya-d5854b17f.pdf.
} 
anak-anak sangat penting untuk diperhatikan. Begitu pentingnya sehingga injil sinoptik harus mencatat kisah tersebut:

1. Matius 19:13-15 Lalu orang membawa anak-anak kecil kepada Yesus, supaya Ia meletakan tangan-Nya atas mereka dan mendoakan mereka; akan tetapi muridmurid-Nya memarahi orang-orang itu. Tetapi Yesus berkata berkata: "Biarkanlah anak-anak itu, janganlah menghalang-halangi mereka datang kepada-Ku; sebab orang-orang yang seperti itulah yang empunya Kerajaan Sorga.” Lalu Ia meletakkan tangan-Nya atas mereka ...

2. Markus 10:13-16 Lalu orang membawa anak-anak kecil kepada Yesus, supaya Ia menjamah mereka; akan tetapi murid-murid-Nya memarahi orang-orang itu. Ketika Yesus melihat hal itu, Ia marah dan berkata kepada mereka: "Biarkan anak-anak itu datang kepada-Ku, jangan menghalang-halangi mereka, sebab orang-orang yang seperti itulah yang empunya Kerajaan Allah. Aku berkata kepadamu: Sesungguhnya barangsiapa tidak menyambut Kerajaan Allah seperti seorang anak kecil, ia tidak akan masuk kedalamnya." Lalu Ia memeluk anak-anak itudan sambil meletakkan tangan-Nya atas mereka Ia memberkati mereka.

3. Lukas 18:15-17 Lalu datanglah orang-orang membawa anak-anaknya yang kecil kepada Yesus, supaya Ia menjamah mereka. Melihat itu murid-murid-Nya memarahi orang-orang itu. Tetapi Yesus memanggil mereka dan berkata: "Biarkanlah anak-anak itu datang kepada-Ku, dan jangan menghalang-halangi mereka, sebab orang-orang yang seperti itulah yang empunya Kerajaan Allah. Aku berkata kepadamu: Sesungguhnya barang siapa tidak menyambut Kerajaan Allah seperti seorang anak kecil, ia tidak akan masuk kedalamnya." 3

Menurut konsep Yahudi tidak ada perbedaan nilai antara duniawi dan rohani, semuanya ada dalam wilayah Tuhan. Itu sebabnya orang Yahudi percaya bahwa "seluruh hidup adalah suci." Pendidikan adalah kegiatan utama dan diintegrasikan dalam kehidupan sehari-hari. Dalam Kitab Talmud dikatakan kalau ingin menghancurkan bangsa Yahudi, kita harus membinasakan guru-gurunya. Bangsa Yahudi adalah bangsa pertama yang memiliki sistem pendidikan nasional (Ul. 6:4-9)

Bahkan sejak usia dini anak-anak Yahudi sudah dibiasakan menaati peraturan agama yang dilakukan sesuai tahapan usianya. Pada usia sekitar 5 tahun anak-anak diberi pelajaran dasar membaca Taurat. Usia 10 tahun mulai diberi pengajaran, yaitu misyna (secara harafiah berarti bahan ulangan yang perlu dihafalkan). Pada usia 12-13 tahun anak-anak wajib menaati sepenuhnya peraturan hukum Yahudi yaitu, mitswoth. Pada tahap ini anak laki-laki telah dianggap sebagai "anak-anak hukum Taurat" yaitu, bar-mitswa segera setelah berusia 13 tahun tambah satu hari.

Sesudah masa pembuangan, pendidikan iman bergeser dari wadah keluarga ke Sinagoge (rumah sembahyang orang Yahudi yang ada hampir di setiap perkampungan). Sinagoge adalah wadah berkumpul sekaligus lembaga tempat orang Yahudi membicarakan berbagai hal menyangkut kehidupan mereka. Dalam wadah ini orang Yahudi belajar Syemo Esre, harfiah berarti delapan belas.

Syemone Esre adalah doa yang terdiri dari 18 pengucapan dan diucapkan setiap hari (pagi, sore dan malam) dalam ibadah di sinagoge. Pembacaan Taurat menduduki posisi penting. Taurat merupakan bagian Kitab Suci yang sentral dan mendasar bagi orang Yahudi. Iman dan kehidupan mereka seluruhnya didasarkan atas Taurat. Pengajaran diberikan dengan cara membaca dan menjelaskan kitab-kitab Musa. Khusus untuk anak-anak pelajaran yang diberikan adalah Syema Yisrael bagaikan kredo

${ }^{3}$ LAI cetakkan 2016 
pengakuan iman dan pengucapan syukur yang dibaca setiap hari (pagi dan malam) dalam ibadah di sinagoge tersebut.

Pada tahun 75 Sebelum Masehi yakni, sebelum kelahiran Tuhan Yesus, bangsa Yahudi mengadakan semacam sekolah dasar yang disebut beth-ha-sefer artinya, rumah sang kitab (bet $=$ rumah; sefer $=$ kitab). Di sekolah ini pengetahuan tentang Taurat diajarkan kepada anak-anak Yahudi. Taurat dibaca berulang-ulang dan anak-anak wajib menghafalnya secara seksama dan harfiah. Sekolah ini bukanlah lembaga tetap yang terdapat di banyak tempat, melainkan hanya suatu kumpulan murid yang diberi pelajaran oleh para ahli Taurat.

Sejak usia 6 atau 7 tahun seorang anak sudah dibawa orangtuanya ke sekolah ini. Tujuannya bukanlah untuk memperoleh pendidikan umum, melainkan khusus mempelajari pengetahuan tentang Taurat. Selanjutnya, pada tingkat yang lebih tinggi lagi setingkat sekolah menengah pertama anak-anak yang berusia 10 atau 11 tahun dikirim ke beth-ha-midrasy (beth = rumah; midrash = pengajaran).

Tujuan sekolah ini bukan hanya untuk mempelajari isi Taurat, tapi yang utama adalah penelitian mengenai manfaat dan maknanya. Sejalan dengan timbulnya sekolah, timbul pula pentingnya jabatan guru. Dalam kebudayaan Yahudi, seorang guru begitu dihormati, sehingga seorang murid patut menunjukkan pengabdian kepada guru sama seperti budak kepada majikannya, kecuali dalam satu hal yang sangat rendah yaitu, membuka tali kasut. ${ }^{4}$

Membawa anak kecil ke bait Allah, atau ke sinagoga untuk di didik oleh seorang guru ternyata sudah menjadi suatu tradisi turun-temurun dalam kehidupan bangsa Israel. Tradisi yang sudah membudaya tersebut juga di alami - terjadi dalam kehidupan Yesus saat berusia delapan hari ia disunat, ${ }^{5}$ dan diserahkan kepada TUHAN. Demikian pula pada saat Yesus sudah berusia dua belas tahun Ia sendiri yang pergi dan bersoal-jawab dengan orang-orang dewasa yang ada di bait Allah pada saat itu. ${ }^{6}$

Pendidikan anak usia dini sampai mereka menjadi remaja begitu sangat penting dalam kehidupan bangsa Israel. Untuk mempersiapkan suatu generasi yang bukan hanya menjadi generasi sukses, berhasil dan beruntung dalam kehidupan mereka, tetapi menjadi generasi yang takut dan percaya pada TUHAN. Begitu penting dan suksesnya pendidikan pada kaum Yahudi sampai orang-orang diluar bangsa Israel, termasuk bangsa Indonesia harus melihat, belajar dan bercermin pada bangsa Israel. Seperti yang ditulis oleh suatu surat kabar nasional yang menulis tentang pendidikan, bahkan semenjak seorang ibu mengandung anaknya. ${ }^{7}$

Seperti yang dilakukan oleh Yesus dengan memarahi murid-murid-Nya yang menghalang-halangi anak-anak kecil datang kepada-Nya, demikian juga setiap orang tua Kristen dan orang percaya harus memberikan perhatian penuh pada pendidikan anak usia dini. Hal tersebut dapat dimulai dengan pasangan calon suami isteri yang harus mendapat berkat Tuhan dengan cara diberkati di hadapan Tuhan dan di hadapan manusia, saat seorang anak sudah lahir harus diserahkan kepada Tuhan, hidup dalam lingkungan gereja, menjadi aktivis gereja sejak usia remaja dan dibaptis seperti Yesus saat sudah akil balik. Semuanya dilakukan untuk mempersiapkan suatu generasi gereja yang bukan sukses, berhasil dan beruntung dalam kehidupan mereka, tetapi penjadi

\footnotetext{
${ }^{4}$ http://gpdiujungmenteng.com/artikel-349-pendidikan-anak-kristen-dan-yahudi-sertapandangan-alkitab.html

${ }^{5}$ Lukas 2:21-24

${ }^{6}$ Lukas 2:46-47

${ }^{7}$ https://fajar.co.id/2019/04/10/mengapa-orang-yahudi-pintar-ini-rahasia-yang-tak-banyak-
} diketahui/ 
generasi penerus gereja yang juga percaya dan mengandalkan Tuhan dalam setiap aspek hidup mereka. Bahkan menjadi suatu generasi yang sukses untuk melaksanakan amanat agung Yesus Kristus memberitakan Kabar Baik - Injil samapai ke ujung dunia.

\section{Metode Penelitian}

Metode penelitian kualitatif deskriptif yang menjelaskan teori-teori yang dikaitkan dengan data-data lainnya ke dalam kerangka berpikir yang dijelaskan secara kualitatif. $^{8}$ Model pembelajatran yang digunakan adalah model pembelajaran kooperatif. ${ }^{9}$ Dengan menggunakan metode $5 \mathrm{P} .{ }^{10}$

Metode kognitif yang dipakai untuk melihat perkembangan cara berpikir anak. Kami membuat pendekatan dengan permainan menebak gambar dan ukuran melalui video, Penelitian ini kami lakukan di kelas sekolah minggu. Kami akan melihat bagaimana mereka merespoi sebuah pertanyaan dalam game tersebut, yang kami tampilkan dalam bentuk video, Sebelum bermain kami membagi mereka dalam kelompok-kelompok kecil untuk dapat memecahkan soal yang kami tampilkan dalam bentuk video secara terbatas atau dengan batas waktu. Saat kami tampilkan soal itu. Setiap anak mulai meresponi dengan melihat Dan menyimak dengan seksama. Anakanak mulai terdiam mengikuti intruksi dari game tersebut. Dalam waktu yang berjalan sekitar 30 detik. Ada yang mulai memberanikan diri untuk mengangkat tangan untuk menjawab soal yang di tampilkan, dari beberapa kelompok yang kami bagi. Suasan jadi ramai dengan anak-anak yang sudah menemukan jawaban, suasana kelas menjadi semakin ramai karena setiap anak ingin menjawab. Kami melihat bagaimana setiap anak bergairah untuk berpikir cepat untuk analisa, pemahaman dalam menyimak dari setiap gambar soal-soal dari video. Ternyata dengan melalui visual banyak anak-anak lebih mudah dan cepat untuk menangkap dan di cernah oleh setiap anak dalam kelas itu.

\section{Hasil dan Pembahasan}

Berdasarkan hasil eksperimen penerapan bermain tebak gambar dan ukuran melalui video, maka kelompok yang diberi perlakuan mengalami peningkatan yang signifikan dibanding kelompok yang menggunakan pembelajaran biasa. Terlihat dari respon yang telah dijelaskan di muka. Khususnya pada kelompok eksperimen mengalami peningkatan pada aspek pengembangan cara berpikir anak dengan teori kognitifnya.

Menurut pemikiran Piaget (1954, 1962, 1965, dalam Hoorn et al. 1999: 34) merupakan sumber bagi para ahli untuk merumuskan kaitan antara bermain dengan kemampuan kognitif anak. Menurut Piaget, perkembangan skema anak bersifat dinamis. Ketika anak telah mengkonsolidasikan untuk naik pada tahapan perkembangan berikutnya, anak tidak menghilangkan kemampuan yang dimiliki sebelumnya.

\footnotetext{
${ }^{8}$ Hengki Wijaya and Helaluddin Helaluddin, Analisis Data Kualitatif Sebuah Tinjauan Teori \& Praktik (Makassar: Sekolah Tinggi Theologia Jaffray Makassar, 2019).

${ }^{9}$ Hengki Wijaya and Arismunandar Arismunandar, "Pengembangan Model Pembelajaran Kooperatif Tipe STAD Berbasis Media Sosial,” Jurnal Jaffray 16, no. 2 (October 6, 2018): 175-96, https://doi.org/10.25278/jj71.v16i2.302.

${ }^{10}$ Roland Walker, "Learning That LASTS," n.d., https://wycliffe.fi/wpcontent/uploads/2018/12/intro-to-learning-that-lasts-walker.pdf.
} 
Kemampuan yang baru dikuasai anak justru akan mengembangkan strategi dan skema anak.

Piaget membagi perkembangan bermain dalam beberapa tahapan yang terkait dengan perkembangan kognitif anak. Tahapan pertama adalah practice atau funtional play dengan karakteristik utama yaitu terkait dengan tahapan intelegensi sensorimotor anak. Piaget menyebut bermain dalam tahapan ini sebagai "a happy display of known action" yaitu bahwa anak-anak mengulangi pengalaman-pengalaman yang mereka rasakan baik dengan obyek maupun dengan tubuhnya. Hal ini dilakukan bayi dengan merengkuh, menarik, menendang, atau mendorong tangannya dimana bayi menikmati kemampuannya dalam menggerakkan anggota tubuhnya. Kegiatan bermain functional play merupakan kegiatan bermain utama yang dilakukan oleh anak hingga usia dewasa. Kesempatan untuk melakukan kegiatan bermain ini menjadi sumber bagi perkembangan dan kesenangan sepanjang hidup. Bermain dalam metode melihat, dan menebak gambar hmerupakan tahapan kedua dalam perkembangan bermain menurut Piaget. Tahapan ini terjadi pada anak usia 18 bulan dengan karakteristik utama yaitu perkembangan kognitif anak pada tahapan praoperasional. Bermain simbolik melibatkan kemampuan anak dalam mengembangkan mental representation yaitu kemampuan untuk membayangkan suatu benda sebagai pengganti benda yang lain dalam kegiatan bermain tersebut. Kemampuan ini akan menjadi dasar dalam pengembangan kemampuan berpikir abstrak dan keterampilan dalam mengorganisir pengalaman. Tiga bentuk permainan simbolik menurut Piaget meliputi permainan konstruktif, permainan dramatik dan permainan dengan aturan.

Implikasi teori Piaget bagi pembelajaran anak usia dini sangat banyak. Anak usia dini menurut Piaget berada pada tiga tahapan pertama. Oleh karena itu, guru harus mampu mendesain kegiatan pembelajaran sesuai tingkat perkembangan anak. Bagi anak yang sedang berada sensorimotor, belajar melalui interaksi organ sensoris dan motoris dengan lingkungan sangat penting. Ia belum bisa berpikir seperti orang dewasa. Begitu pula anak fase praoperasional, jangan dipaksa menarik kesimpulan dari dua variabel yang tidak diamati langsung. Memberikan pengalaman nyata jauh lebih berharga daripada mencekoki anak dengan konsep yang harus dihafalkan. Anak pada fase konkret operasional paling baik belajar dari benda-benda atau obyek seacara langsung. Teori Piaget kelak menjadi dasar paham konstruktivisme. 


\section{DAFTAR PUSTAKA}

Helaluddin, Helaluddin, and Hengki Wijaya. "Pengembangan Kompetensi Pendidik Di Perguruan Tinggi Dalam Menyonsong Era Revolusi Industri 4.0,” 2019. https://repository.sttjaffray.ac.id/id/publications/273069/pengembangankompetensi-pendidik-di-perguruan-tinggi-dalam-menyonsong-era-revolu.

Holis, Ade. "Belajar Melalui Bermain untuk Pengembangan Kreativitas dan Kognitif Anak Usia Dini.” Jurnal Pendidikan UNIGA 10, no. 1 (February 20, 2017): 23 37.

Ipaq, Eli Wilson, and Hengki Wijaya. "Kepemimpinan Para Rasul Dan Relevansinya Bagi Pemimpin Gereja Di Era Revolusi Industri 4.0." Integritas: Jurnal Teologi 1, no. 2 (2019): 112-22.

Keegan, Sheila. Qualitative Research: Good Decision Making through Understanding People, Cultures and Markets. Market Research in Practice Series. London ; Philadelphia: Kogan Page, 2009.

Sahiu, Sifra, and Hengki Wijaya. "Hubungan Motivasi Belajar Ekstrinsik Terhadap Hasil Belajar Psikomotorik Pada Mata Pelajaran Agama Kristen Kelas V Di SD Zion Makassar.” Jurnal Jaffray 15, no. 2 (September 22, 2017): 231. https://doi.org/10.25278/jj71.v15i2.262.

Sutarto, Sutarto. "Teori Kognitif Dan Implikasinya Dalam Pembelajaran.” Islamic Counseling: Jurnal Bimbingan Konseling Islam 1, no. 2 (December 28, 2017): 1. https://doi.org/10.29240/jbk.v1i2.331.

Walker, Roland. "Learning That LASTS," n.d. https://wycliffe.fi/wpcontent/uploads/2018/12/intro-to-learning-that-lasts-walker.pdf.

Wijaya, Hengki. "Pendidikan Neurosains Dan Implikasinya Dalam Pendidikan Masa Kini," 2018. https://repository.sttjaffray.ac.id/media/269017-pendidikanneurosains-dan-implikasinya-d-5854b17f.pdf.

Wijaya, Hengki, and Arismunandar Arismunandar. "Pengembangan Model Pembelajaran Kooperatif Tipe STAD Berbasis Media Sosial." Jurnal Jaffray 16, no. 2 (October 6, 2018): 175-96. https://doi.org/10.25278/jj71.v16i2.302.

Wijaya, Hengki, and Helaluddin Helaluddin. Analisis Data Kualitatif Sebuah Tinjauan Teori \& Praktik. Makassar: Sekolah Tinggi Theologia Jaffray Makassar, 2019. 